\title{
Does Teacher Collaboration Improve Student Achievement? Analysis of the German PISA 2012 Sample
}

\author{
Julio Gregorio Mora-Ruano ${ }^{1 *}$, Jörg-Henrik Heine ${ }^{1}$ and Markus Gebhardt ${ }^{2}$ \\ ${ }^{1}$ TUM School of Education, Technical University of Munich, Munich, Germany, ${ }^{2}$ Faculty of Rehabilitation Sciences, Technical \\ University of Dortmund, Dortmund, Germany
}

During the past decades, teacher collaboration has received increasing attention from both the research and the practice fields. However, little has been said about its relationship with student achievement. In the present study, using data from the representative PISA 2012 German sample, we investigate the effects that the three forms of teacher collaboration proposed by PISA namely instruction- project- and organization related have on student achievement. We conducted exploratory and confirmatory factor analysis to test the factorial validity of the instrument. After some re-specifications to the questionnaire, the results from a full structural equation model suggest that a small positive effect can be seen, only when teachers specifically discuss student achievement.

\section{OPEN ACCESS}

Edited by:

Gary James Harfitt,

The University of Hong Kong,

Hong Kong

Reviewed by:

Maria Antonietta Impedovo, Aix-Marseille Université, France Theresa Catalano, University of Nebraska-Lincoln, United States

*Correspondence: Julio Gregorio Mora-Ruano juliogregorio.mora-ruano@tum.de

Specialty section: This article was submitted to Teacher Education, a section of the journal Frontiers in Education

Received: 03 June 2019 Accepted: 29 July 2019 Published: 13 August 2019

Citation:

Mora-Ruano JG, Heine J-H and Gebhardt M (2019) Does Teacher

Collaboration Improve Student Achievement? Analysis of the German PISA 2012 Sample. Front. Educ. 4:85. doi: 10.3389/feduc.2019.00085
Implications for research and praxis are also presented and discussed.

Keywords: teacher collaboration, student achievement, causal inference, Germany, PISA 2012, structural equation model

\section{INTRODUCTION}

Collaboration among teachers is a force that positively influences the whole school community. DuFour et al. (2005) advocate to increment collaborative activities in the form of professional learning communities, stating that such collaborative communities "hold out immense, unprecedented hope for schools and the improvement of teaching" (p. 128). Positive effects for teachers were found in improved self-efficacy (cf. Puchner and Taylor, 2006), increased teaching effectiveness (cf. Graham, 2007), and improvement of instructional quality (cf. Jackson and Bruegmann, 2009; Hochweber et al., 2012). These positive effects will improve their quality as professionals and as Hattie (2003) suggests, teacher quality alone accounts for $30 \%$ of the variance in student performance. The communities that will be formed by working collaboratively will enhance teacher effectiveness and expertise (Hattie, 2015).

The positive influence of teacher collaboration transcend the teacher community; research has shown that professional collaborative activities might have a positive effect on student achievement (cf. Lee and Smith, 1996; Louis et al., 2010; Dumay et al., 2013). Goddard et al. (2010) found a significant direct positive effect on student achievement while Lara-Alecio et al. (2012) found that students whose teachers participated in collaborative activities, such as instruction strategies, scored higher in science and reading achievement than students whose teachers did not attend such professional development activities. However, because of its relatively recent emergence, empirical evidence of the effects of teacher collaboration on student achievement is limited (Moolenaar et al., 2012). Research tends to investigate teacher collaboration as a single construct and thus, information about the benefits that can be drawn from specifics form of collaboration are unknown (Reeves et al., 2017). Furthermore, Scheerens (2000) points out that most of the data on school effectiveness has been gathered in American elementary schools (p. 44). 
In this paper, by using the representative German data from PISA-2012 (Prenzel et al., 2015), we investigate the extent to which three different forms of teacher collaboration, namely instruction- project- and organization-related, influence student achievement. We use the students' grades retrieved in the first half year of the academic period 2011/2012 in the subjects of mathematics, German language, biology, physics, and chemistry. To our knowledge, this is the only study that has used this dataset in order to investigate these variables.

\section{THEORETICAL BACKGROUND}

Given the huge impact that teachers play in the performance of their students and the continual acknowledgment of teacher collaboration as a core element for the professional development of the school and its members, it is not surprising that many official policies and education reforms around the world plead for more collaborative practices among teachers. Countries like Denmark, Finland, Norway, and Hungary, among others, dedicate a fair amount of time to activities of teacher collaboration (OECD, 2004). In Finland, for example, the curriculum reform of 2016 stated that a "collaborative atmosphere" (Halinen, 2015) is a key aim for school improvement, given that by working together across school subjects the objectives of the new curriculum, such as teacher competence development, can be met. Another example of the high value placed on teacher collaboration can be found in the United States; Melanie Hirsh states that: "the system at the school level is supported by state and federal policies that encourage regular teacher collaboration [...] and provides needed resources to give teachers time and opportunity to make this happen" (Darling-Hammond et al., 2009, p. 3).

Research has also found a positive and significant association between teacher collaboration and job satisfaction (cf. OECD, 2014; Mostafa and Pál, 2018), which is a core element of an effective teacher. In fact, Johnson (2003) found "important emotional and psychological benefits associated with working closely with colleagues in teams" (p. 343) when planning, discussing, and working in collaborative teams (ibid, p. 344). One reason for this might be that when teachers collaborate, feelings of isolation are mitigated. According to Lortie (1975) isolation is a defining characteristic of the teaching profession which ultimately can lead to a series of negative aspects such as job dissatisfaction and burnout (Gaikwad and Brantly, 1992) as well as a sense of being completely alone (Fimian, 1982; Eisner, 1992). Because through collaboration joint work is fostered to reach specific student learning goals, competition among colleagues is prevented (Williams, 2010).

Additionally, some studies have found a positive effect of teacher collaboration on student achievement (cf. Lee and Smith, 1996; Borko, 2004; Louis et al., 2010; Dumay et al., 2013). For instance, Goddard et al. (2010) found a significant direct positive effect on student achievement in the subjects of mathematics and reading as well as an indirect effect of shared instructional leadership on student achievement only when mediated through collaboration. Vincent-Lancrin et al.
(2017), as part of the OECD project Measuring Innovation in Education identified teacher collaboration (measured in forms of peer observation and discussion with peers) as a factor that fosters student scores. Hargreaves and Fullan (2012) argue that "a more collaborative and collegial profession improves student learning and achievement" (p. xii). Darling-Hammond et al. (2017) take a similar stance, as they have shown that student achievement can be positively influenced when "effective collaborative structures for teachers to problem-solve and learn together are utilized" (p. 10). In their research review (ibid), they identified teacher collaboration as one of seven factors that constitute effective professional development stating that, "by working collaboratively, teachers can create communities that positively change the culture and instruction of their entire grade level, department, school, and/or district" (p. v). This has also been suggested for general and special education teachers in inclusive classrooms, where collaboration has been identified as an important factor for the inherent challenges that educators in such environments find (Gebhardt et al., 2015). Schwab (2017) has also found that students in inclusive classrooms prefer teachers that work in teams (co-teaching) because they feel more supported. Given that "collaboration make teaching less stressful and more satisfying” (Burns and Darling-Hammond, 2014, p. ii) arguably teachers can focus on other aspects such as teaching practices, which in turn have considerable positive effects on student achievement (cf. Schacter and Thum, 2004; HidalgoCabrillana and Lopez-Mayan, 2015). For instance, Reeves et al. (2017) suggest that through collaboration, teachers may have more time to reflect on their teaching practices and thus, assess if what they are doing works and accordingly change or reinforce their actions and behaviors in the classroom. In a study conducted in three schools in Norway over a single year, Svendsen (2016) found out that through collaboration practices, teachers were able to adopt a new teaching form called "inquiry-based science teaching," which in turn allowed teachers to gain confidence, think critically and reflect about their teaching practices. The results of a study conducted by Ronfeldt et al. (2015) in 336 Miami-Dade County public schools indicated strong correlational and possibly causal effects "of collaboration on teachers' and schools' effectiveness at improving student achievement" (p. 508). They argued that an increase in the quality of collaboration can lead to school improvement and showed that student achievement is higher in schools with strong collaborative environments. Ronfeldt's findings showed that teachers and students benefited from collaboration in the areas of instructional strategies and curriculum, instructional approaches to groups or individuals, and approaches to assessment.

However, as Friend and Cook (2009) indicate, in order to create thriving collaboration communities, specification of goals, and outcomes is necessary as well as the allocation of time to collaborate. According to Dufour et al. (2006) a lack of time and a lack of leadership support are among the factors that can cause a Professional Learning Communities (PLC) to fall apart. Research has shown that goals and outcomes must be set from both principals and teachers in order to avoid hierarchical systems of control which according to Hargreaves (2003) are paths which will ultimately lead to "artificial collaboration." Additionally, 
studies concerning the influence of teacher collaboration on student achievement are insufficient (cf. Goddard et al., 2007; Desimone, 2009; Meirink et al., 2010; Kullmann, 2013). Goddard et al. (2010) argue that the majority of the existing literature investigates the effects on teachers and not on students. Because research on teacher collaboration and its effects on student achievement is still in an emerging phase, further examination is essential to understand its connections and to expand related findings (ibid).

This is, however, a complicated task given the definitional inconsistencies of teacher collaboration. Woodland et al. (2013) write that a definition of teacher collaboration "is elusive, inconsistent, and often theoretical" (p. 443). The need to reach a consistent definition is well-documented in the literature (cf. Bondorf, 2013; Aldorf, 2016), for instance Kelchtermans (2006) highlight the importance and necessity of further definition and specification of teacher collaboration, in order to "properly discuss the issue" (p. 220). The absence of a unified theory on the effects of teacher collaboration, as well as a consistent definition of the construct, lead to mixed and inconsistent results which could make their interpretation very difficult. Although originally denominated "collaborative consultation" and aimed specifically for interactions between general and special educators, Idol et al. (as cited in Luster, 1993) provide one of the first operationalized definitions: "an interactive process that enables people with diverse expertise to generate creative solutions to mutually defined problems" (p. 1). This definition lays the foundations for later expanded definitions such as occupational and organizational psychology (Piepenburg, 1991; Spieß, 2004), political education (Reinhardt, 2000), or pedagogicoriented (Esslinger, 2002). Taking as a starting point these different approaches to the definition, Mora-Ruano et al. (2018) provide one definition aimed exclusively at the teacher level in which aspects such as relational trust, school administration, as well as coordination and exchange of ideas and materials between teachers play a central role for the teaching effectiveness.

The structural characteristics of teacher collaboration are also manifold. Friend and Cook (1992) listed six defining features of collaboration: is voluntary; requires parity among participants; is based on mutual goals; depends on shared responsibility for participation and decisionmaking; individuals who collaborate share their resources, and individuals who collaborate share accountability for outcomes. Little (1990) identified four different types of collaborative elements, including storytelling and scanning for ideas, aid and assistance, sharing, and joint work. The seminal work from Gräsel et al. (2006) propose a model of teacher collaboration with three specific forms of collaboration: exchange, synchronization, and co-construction. Finally, the Leibniz Institute for the Education of Natural Sciences and Mathematics (IPN) constructed three different forms of collaboration from the questionnaire for teachers used in PISA 2012 namely:

Instruction-related (IRC) which involve elements related to the preparation and development of didactical skills. This form is measured with questions referring to the frequency with which teachers exchange teaching materials, exam questions and work together for the preparation of individual and follow-up lessons. Project-related (PRC) which include aspects related to the planning of lessons as well as the preparation of written exams and the joint planning and implementation of lessons which encompasses peer observation as well. Organization, performance, and problems related (ORC) covering aspects such as strategies to help students based on their academic performance within and across subjects as well as strategies to dealing with homework (Frey et al., 2009; Mora-Ruano et al., 2018).

For the German context which this paper addresses, Drossel (2015) states that findings concerning teacher collaboration in Germany are "inconsistent and partially contradictory" (p. 55), although in Germany, collaboration is considered a fundamental part of school development (Kultusministerkonferenz, 2003; Kulturministerkonferenz, 2014), and a key aspect of models of professional learning which attempt to close the achievement gap. Furthermore, it is considered a central element for the effective implementation of educational standards (Trumpa et al., 2016). Although the focus of this paper lies on the German context, the results that we present can help researchers and practitioners alike determine if a particular form of collaboration can influence student achievement in other contexts.

\section{RESEARCH QUESTION AND HYPOTHESIS}

Our review of the literature has identified concrete aspects that can be positively influenced through teacher collaboration. Some of these aspects, such as student achievement, are currently in an emergence phase and thus require more investigation to expand the knowledge base about which specifics forms of collaboration can influence them. Therefore, in this study we would like to know to what extent teacher collaboration influences student achievement (measured in the subjects of mathematics, German language, biology, physics, and chemistry) dependent on the form of collaboration. To our knowledge, no other study has investigated the aforementioned variables with the representative dataset from PISA 2012 in Germany. We hypothesize that student achievement will only be positively influenced by the third form of collaboration (organization, performance, and problem-related, ORC), because this is the only form of collaboration that is explicitly focused on student achievement. The other two forms, IRC (instruction related) and PRC (project related) may have an influence on other aspects but not on student achievement.

\section{METHODS}

\section{Design}

PISA employs a multi-layered (stratified) probability sample from a list of all schools provided by the 14 Land Statistical Offices in Germany. This sample is drawn from two steps: first, schools are randomly selected, and then within each selected school, classes, students or teachers are randomly selected (Sälzer and 


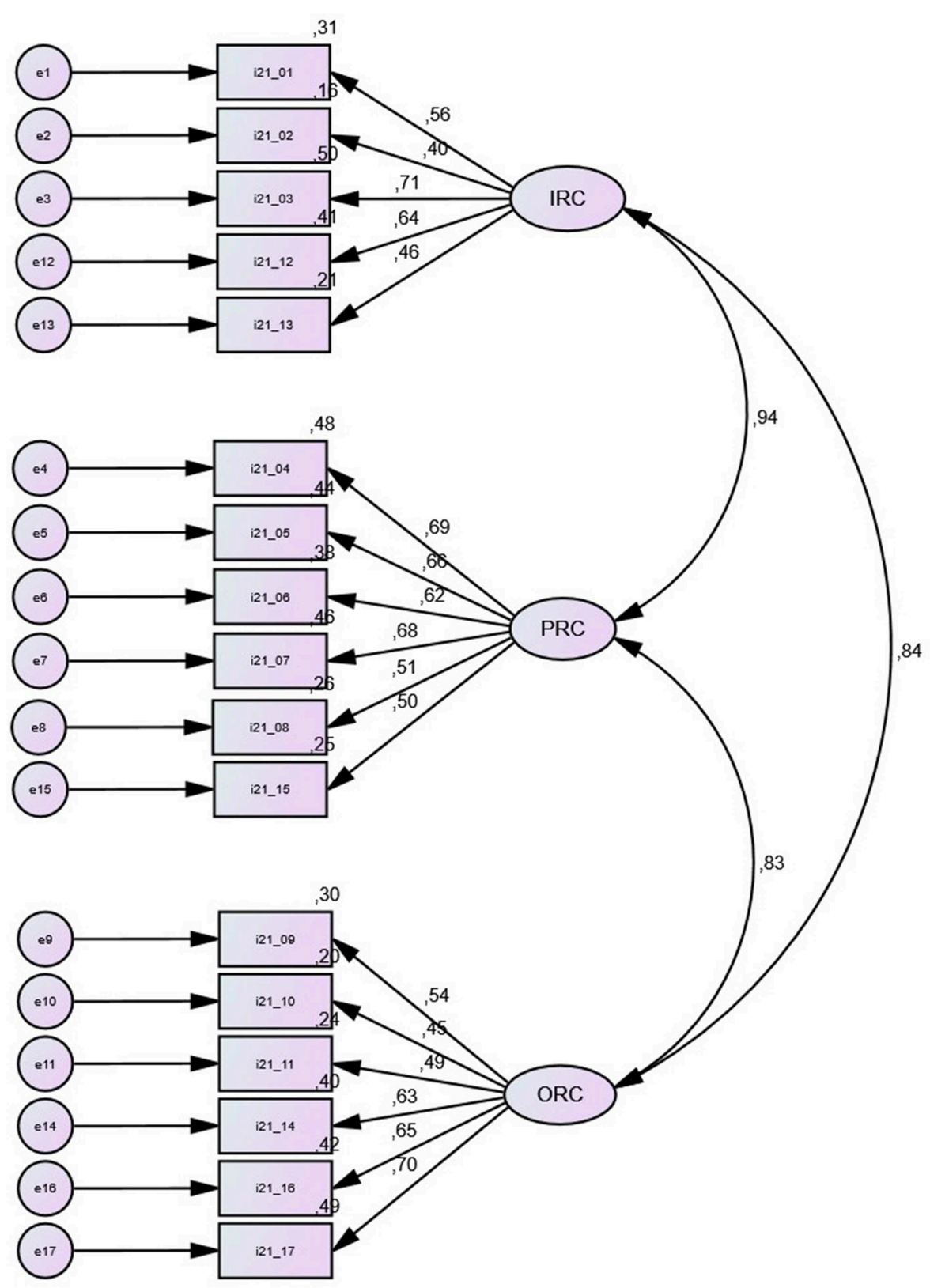

FIGURE 1 | Initial hypothesized measurement model.

Prenzel, 2013). For a detailed explanation of the design used in PISA 2012, see (ibid).

\section{Participants}

To investigate the extent to which teacher collaboration influences student achievement, we carry out a secondary analysis of the representative German PISA 2012 data. In order to properly assess these effects, two datasets (teacher and student) were matched, resulting in a subsample of 869 schoolteachers ( $44.5 \%$ female, $55.5 \%$ male) with a mean age of 47.3 and in a corresponding subsample of 869 students.

\section{Measures}

In PISA 2012 frequency of teacher collaboration is measured through question 21 in the in the National Questionnaire for Teachers (by Bosker and Hendriks, 1997, see Appendix A) and investigated through three different forms of collaboration from the IPN: instruction-, project- and organization, performance, and problems related. Student achievement is measured through the retrieved students' grades in the first half year of the academic period 2011/2012 in the subjects of mathematics, German language, biology, physics, and chemistry. In order to provide a valid framework we will use on the one hand, the definition of 
teacher collaboration from Mora-Ruano et al. (2018) and on the other hand, the three forms of collaboration described above.

\section{Analysis}

All analyses were conducted using the software packages SPSS 25 and AMOS 25. A full structural equation model was run to investigate the impact that teacher collaboration has on student achievement. Structural equation modeling allows to test statistically if there are "causal processes that generate observations on multiple variables [and] to hypothesize and specify in detail the process of interrelated effects operating among variables" (Bentler, 1988, p. 317). This is carried out through simultaneous analyses such as confirmatory factor analysis, linear regression and path estimates (cf. Bollen, 1989; Byrne, 2016). All this is in particular appropriate for our study, given that we want to investigate the effects that teacher collaboration has on student achievement.

Before modeling the final structural model and matching the two datasets, we conducted a confirmatory first order factor analysis in order to test the factorial validity of the proposed model from PISA (Figure 1) and to verify if model re-specification was required. Anderson and Gerbing (1988) suggested that before examining the structural relationships in a model, a first step in form of a confirmatory factor analysis is preferred because it ensures that the latent constructs are adequately measured. We used the Maximum Likelihood (ML) estimator because it uses all the available data for each person, estimating missing information from relations among variables in the full sample (Schafer and Graham, 2002). Hypothesis testing was conducted at significance level of $p<0.05$. Table 1 shows a comparison of the model fit results between the original hypothesized model and the two re-specifications which were conducted because the initial model proved to be ill-fitting. They were made with the solely purpose to find a scale and an instrument that actually fit the data. Reasons and theoretical basis are also provided justifying every step in the re-specifications.

In the literature, several recommendations have been made for the number of fit indices to be reported (c.f., Bollen, 1990, Fan et al., 1999, Hu and Bentler, 1999, Schumacker and Lomax, 1996). Brown (2006) recommended the use of fit indices from each of the three categories of fit estimates: (a) an index for a model's absolute fit, (b) an index for fit adjusting for model parsimony, and (c) an index for comparative or incremental fit. Following this recommendation, we selected the following fit indices: the standardized root mean square (SRMR), the TuckerLewis Index (TLI; Tucker and Lewis, 1973), the root mean-square

TABLE 1 | Comparison of model fit values between original and respecified measurement models.

\begin{tabular}{lcccccccc}
\hline & $\chi^{2}$ & $d f$ & $p$ & CFI & TLI & RMSEA & RMSEA Cl 90 & SRMR \\
\hline Original & $1,714,409$ & 116 & 0.000 & 0.843 & 0.816 & $0.085^{*}$ & $0.081-0.089$ & 0.0582 \\
After EFA & 136.674 & 17 & 0.000 & 0.967 & 0.945 & $0.061^{*}$ & $0.052-0.070$ & 0.0316 \\
After CFA & 70.872 & 16 & 0.000 & 0.985 & 0.973 & $0.042^{\star \star}$ & $0.033-0.053$ & 0.0213 \\
\hline${ }^{*} p \leq 0.05 ;{ }^{* *} p=0.883$. & & & & & & & \\
\hline
\end{tabular}

error of approximation (RMSEA; Steiger and Lind, 1980), and the comparative fit index (CFI; Bentler, 1990). We report the chisquare and its significance value as it is the original fit index and the basis for most other fit indices. However, it is worth noting that the chi-square is no longer relied upon as a basis for acceptance or rejection because it is very sensitive to sample size (Schermelleh-Engel et al., 2003; Vandenberg, 2006), and it is affected by several factors like model size, normal distribution of the variables as well as omission of variables (Newsom, 2018). Additionally several recommendations about the cut-off values to determine goodness-of-fit have been suggested and although this has been an object of study for a long time, there is still some disagreement as to the cut-off values for fit indices (Marsh et al., 2004, 2005). For our study, the recommended joint criteria to retain a model by $\mathrm{Hu}$ and Bentler (1999) and by MacCallum et al. (1996) are used. Hu and Bentler (1999) suggested values for the CFI and TLI above 0.95 and values below 0.05 for the SRMR, whereas MacCallum et al. (1996) defined RMSEA values of $0.01,0.05$, and 0.08 to indicate excellent, good, and mediocre fit, respectively.

\section{Exploratory Factor Analysis}

Given that the proposed structure resulted in an ill-fitting model, an exploratory factor analysis (EFA) was conducted to further investigate the adequate number of constructs and structure of this measure. This analysis is intended to explore the data

TABLE 2 | EFA of forms of teacher collaboration.

\begin{tabular}{|c|c|c|c|c|}
\hline & \multicolumn{3}{|c|}{ Factor } & \multirow[b]{2}{*}{ Communality } \\
\hline & 1 & 2 & 3 & \\
\hline i21_16 & 0.558 & $0.200^{\star}$ & $0.269^{\star}$ & 0.424 \\
\hline i21_17 & 0.550 & $0.297^{\star}$ & $0.239^{\star}$ & 0.447 \\
\hline i21_11 & 0.527 & $0.138^{\star}$ & - & $0.302^{\star \star \star}$ \\
\hline i21_14 & 0.523 & $0.264^{\star}$ & $0.162^{*}$ & 0.370 \\
\hline i21_12 & 0.496 & $0.413^{\star \star}$ & $0.158^{\star}$ & 0.441 \\
\hline i21_09 & 0.467 & $0.237^{\star}$ & $0.143^{\star}$ & $0.294^{\star \star \star}$ \\
\hline i21_13 & 0.427 & $0.145^{\star}$ & $0.224^{\star}$ & $0.253^{\star \star \star}$ \\
\hline i21_10 & 0.422 & $0.182^{\star}$ & - & $0.216^{\star \star \star}$ \\
\hline i21_06 & $0.193^{\star}$ & 0.701 & - & 0.537 \\
\hline i21_04 & $0.193^{\star}$ & $0.569^{\star \star}$ & $0.419^{\star \star}$ & 0.537 \\
\hline i21_05 & $0.328^{\star}$ & 0.560 & $0.181^{\star}$ & 0.454 \\
\hline i21_08 & $0.306^{\star}$ & 0.518 & - & 0.363 \\
\hline i21_07 & $0.390^{\star \star}$ & $0.465^{\star \star}$ & $0.270^{\star}$ & 0.441 \\
\hline i21_01 & $0.153^{\star}$ & $0.229^{\star}$ & 0.648 & 0.496 \\
\hline i21_02 & $0.160^{\star}$ & - & 0.607 & 0.395 \\
\hline i21_03 & $0.225^{\star}$ & $0.495^{\star \star}$ & $0.496^{\star \star}$ & 0.542 \\
\hline i21_15 & $0.443^{\star \star}$ & - & $0.445^{\star \star}$ & 0.400 \\
\hline Eigenvalue & 6,026 & 1,378 & 1,241 & \\
\hline$\%$ of Variance & 35,446 & 8,104 & 7,303 & \\
\hline
\end{tabular}

Items with an asterisk were deleted using the following criteria.

${ }^{\star}$ Factor loadings with a value $<0.4$.

${ }^{\star *}$ Cross-loadings.

${ }^{\star * \star}$ Communalities lower or marginally above than 0.3 . 
when the links between the observed and latent variables are unknown or uncertain (Hair et al., 2014; Byrne, 2016). In other words, this allowed us to organize the items of the questionnaire better in relation to the three proposed forms of collaboration.
Prior to conducting the EFA a bivariate correlation was carried out in order to test the factorability of the items. No signs of multicollinearity were found as none of the items correlated more than the threshold of 0.8 suggested by Field (2013). Nine items were eliminated because they did not contribute to a simple

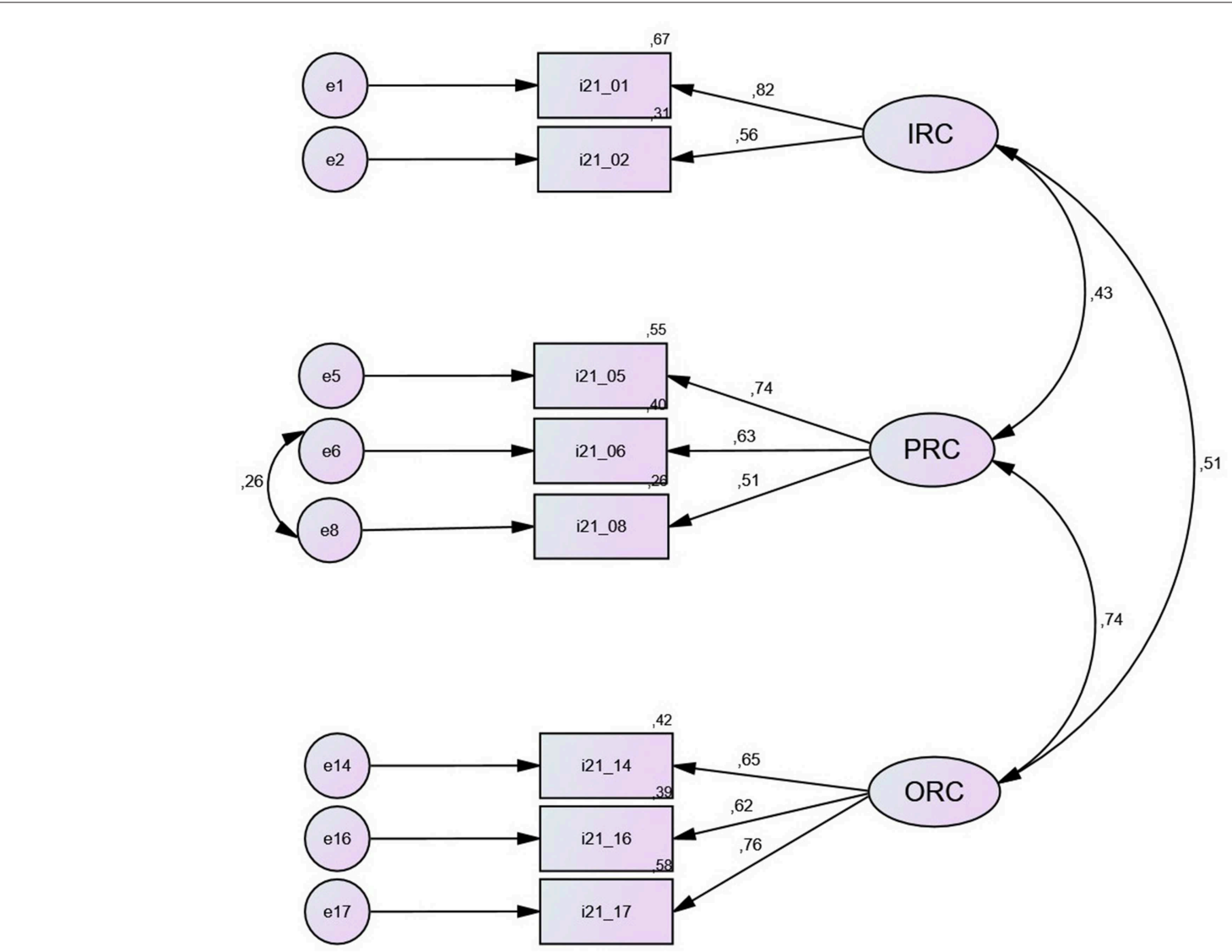

FIGURE 2 | Final measurement model with standardized values and regression weights.

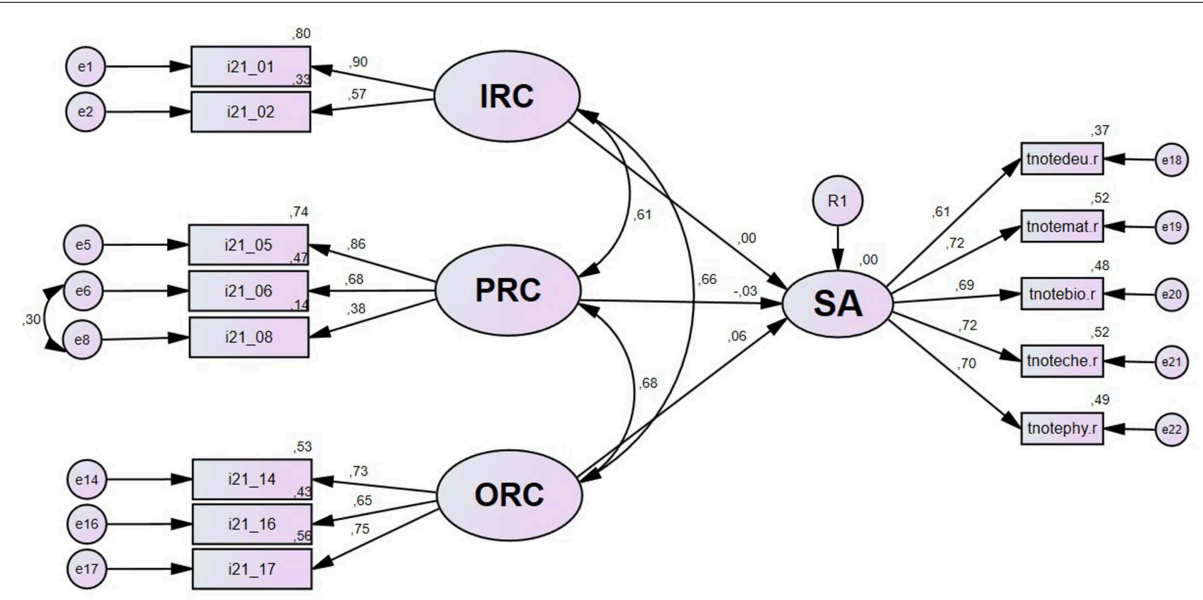

FIGURE 3 | Structural model of three forms of collaboration and student achievement (SA). 
factor structure and failed to meet a minimum criteria of having a primary factor loading of 0.4 or above, and no cross-loading of 0.2 or above as suggested by Nunnally and Bernstein (1994). Furthermore, because their communalities were lower than 0.3 or only marginally above (Item 11) and thus were not explained adequately by the factors (see Table 2 ).

Secondly, the Kaiser-Meyer-Olkin measure of sampling adequacy was 0.916 falling in the range that Kaiser (1974) defined as "marvelous." The Bartlett's test of sphericity was significant, $\chi^{2}(136)=10,297.8, p<0.05$. The diagonals of the anti-image correlation matrix were also all over 0.5 . Reliability of the scales were measured through Cronbach's $\alpha$ and all of them resulted in an acceptable value. Hair et al. (2014) deemed values of 0.60-0.70 the lower limit of acceptability. IRC $\alpha=0.63$; PRC $\alpha=0.70$, and ORC $\alpha=0.71$. All items appeared to be worthy of retention.

\section{Confirmatory Factor Analysis}

Subsequently, a confirmatory factor analysis was conducted in order to test the factorial validity of the re-specified instrument, resulting in a better model than the original. However, this model only partially fulfilled the required criteria to be retained (see Table 2). After an inspection of the regression weights, the error terms of the items six and eight were correlated because they had an unusually big value in comparison to the other items, contributing to a misspecification of the model. "Correlated error terms in measurement models represent the hypothesis that the unique variances of the associated indicators overlap; that is, they measure something in common other than the latent constructs that are represented in the model" (Dattalo, 2013, p. 118). Given that these two items have a similar wording, one can infer that they share something in common; although the specific nature of the "something" is unknown, one can argue that one central aspect in both cases changes, namely: the teachers are no longer alone and are accompanied by a colleague in the classroom. Therefore, the correlation of these error terms is supported by what we consider a substantive rationale and not only because of statistical reasons or for purposes of achieving a better fitting model. Figure 2 shows the final measurement model with its standardized values and regression weights. This model will be used to perform our main analyses.

\section{RESULTS}

After validation of the measurement model, the relationship between the three forms of collaboration and student achievement was estimated through a structural equation model (see Figure 3). It consists of a measurement model that defines the latent constructs and a structural model that defines the relationships among the latent variables (Bollen, 1989). The measurement model specifies the outcomes variables measured. Overall, the model produced a good fit of the data, $\chi^{2}=139,513$ $(p \leq 0.05), \mathrm{df}=58, \mathrm{CFI}=0.975, \mathrm{TLI}=0.960, \mathrm{RMSEA}=0.040$ (90\% CI $=0.032-0.049)$ PCLOSE $=0.970$. Given that student achievement data contained missing values and that AMOS does not provide the full information maximum likelihood estimation, the SRMR was not calculated for the final model. Nonetheless, all values are well within the threshold for a good fit.
Factor loadings for the complete model can be seen in Table 3. The third form of collaboration [organization, performance, and problems related (ORC)] was the only form that had a positive influence on student achievement (SA) (standardized coefficient $=0.06$ ). The other two forms, Instruction-related (IRC) and Project-related (PRC) collaboration, did not have an effect on student achievement (standardized coefficients $=-0.03$ and 0.00 , respectively). However, these effects were non-significant.

\section{DISCUSSION}

The central role that teachers play every day at school is well documented in the literature. For instance, Kunter and Pohlmann (2009) write that "teachers are largely responsible for the success of education" (pp. 262), thus it is of critical importance to investigate which factors can positively influence them as professionals and as individuals. Teacher collaboration is one factor that is consistently presented as decisive for the improvement of the school and its members. Ditton (2000) places teacher collaboration (at the instruction level) as a factor in a model for school quality. Previous research has found positive effects of teacher collaboration on student achievement (cf. Goddard et al., 2010; Lara-Alecio et al., 2012). Reeves et al. (2017) argue that related findings are limited, given the tendency to investigate teacher collaboration as a single construct instead of using different forms. Thus, by analyzing the representative German sample from PISA 2012, we expand the existing literature by investigating the effects that three forms of collaboration [instruction-related (IRC), project-related (PRC) and organization, performance, and problems-related (ORC)] have on student achievement as measured by grades

TABLE 3 | Factor loadings and significance values of the final model.

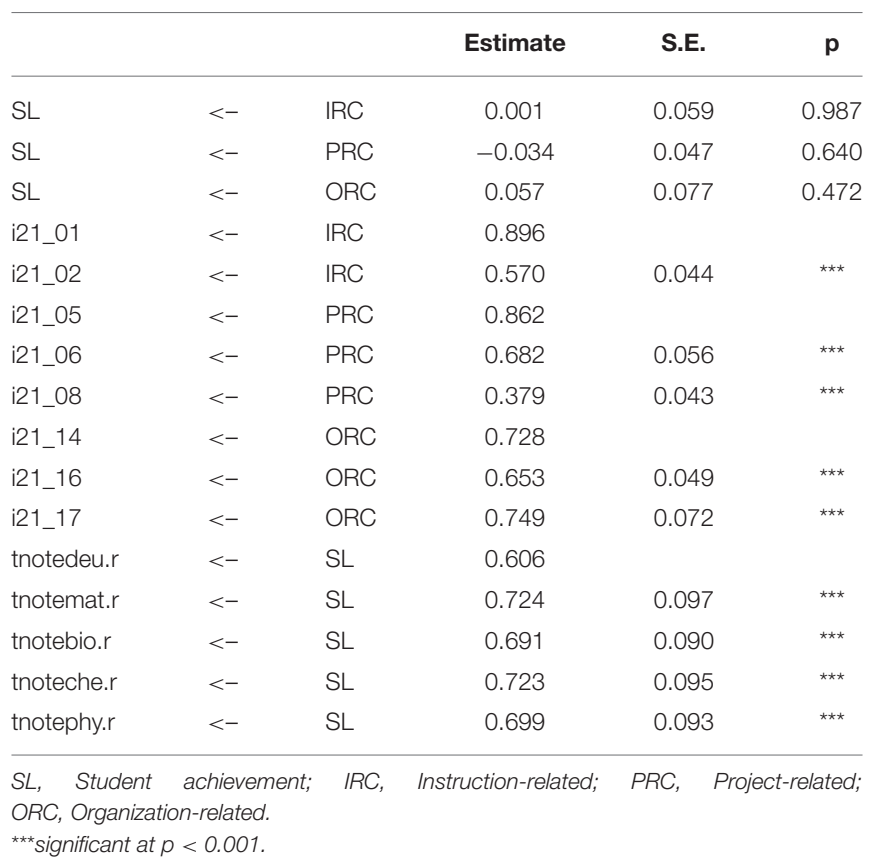


from the subjects of mathematics, German language, biology, physics and chemistry. Although from our analysis, the effects of the three forms of collaboration on student achievement were non-significant, the direction of the relationships were as expected. That is, only the third form of collaboration (ORC) were positive. The other two forms IRC and PRC yielded no direction whatsoever and a negative direction, respectively. We expected this because the items belonging to the ORC dimension were the only ones that dealt with outcomes related to student achievement. The fact that the other two forms of collaboration (IRC and PRC) have a zero and a negative standardized regression weight does not mean that the more a teacher collaborates along these dimensions, the worse the students' achievement will be. These results are an indication that these two forms (IRC and PRC) may have effects on other aspects such as increased job satisfaction and/or decreased teachers' workload, but no effect on student achievement. Additionally, the effects of the forms of collaboration on student achievement may be delayed in time.

Two major limitations of our study warrant attention. First, given the inherent limitations of the data we used, only a direct effect of teacher collaboration on student achievement could be modeled. However, teacher collaboration encompasses very complex forms of interactions among its individuals and therefore, it would be advisable for future studies to include moderation or mediation variables such as principal leadership, teachers' self-efficacy or student motivation in order to give a better explanation of the effects of teacher collaboration on student achievement. The data from the PISA 2012 German questionnaire had no information regarding these variables, making it impossible to include them in the model. Second, the factorial validity of the original questionnaire proved to be problematic and therefore we conducted two re-specifications that despite yielding good results, had fewer items than the original, and as a result, some information was inevitably lost. It would be advisable to rethink the theory that supports the model as well as the instrument itself.

From our findings, implications for both the research and praxis can be drawn. Future studies should investigate teacher collaboration as a construct that encompasses more than one form, only then can precise information be drawn about the structures, mechanisms and effects surrounding these practices, which in turn allow teachers, principals, and other participating actors to develop better collaborative practices. The implication for praxis is that more attention to aspects regarding students' achievement, such as joint discussion and advice between

\section{REFERENCES}

Aldorf, A.-M. (2016). Lehrerkooperation und die Effektivität von Lehrerfortbildungen. Wiesbaden: Springer VS. doi: 10.1007/978-3-658-11677-4

Anderson, J. C., and Gerbing, D. W. (1988). Structural equation modeling in practice: a review and recommended two-step approach. Psychol. Bull. 103, 411-423. doi: 10.1037/0033-2909.103.3.411

Bentler, P. M. (1988). "Causal modeling via structural equation systems," in Handbook of Multivariate Experimental Psychology. Perspectives on Individual teachers for students with different performance levels, should be made because these collaboration practices can positively influence students' achievement.

\section{CONCLUSION}

Our goal was to investigate to what extent the three forms of teacher collaboration proposed by the German teacher questionnaire from PISA 2012 influence student achievement. Our results show that a positive effect on student achievement can be established only when teachers specifically collaborate to discuss or advise each other about student performance. However, the inclusion of additional variables in a future model, could better explain these effects.

\section{DATA AVAILABILITY}

The datasets generated for this study will not be made publicly available permission to access and use the data for scientific purposes must be granted through the German Research Data Center (FDZ) at the Institute for Educational Quality Improvement (IQB).

\section{ETHICS STATEMENT}

Permission to access and use the data for scientific purposes was granted through the German Research Data Center (FDZ) at the Institute for Educational Quality Improvement (IQB). As per OECD guidelines and German national regulations (KMK) no new ethics approval was required. The authors did not have access to identifiable information.

\section{AUTHOR CONTRIBUTIONS}

JM-R drafted the manuscript, wrote the literature background, performed, and interpreted the statistical analyses. J-HH provided expertise on data analysis and performed some of these analyses (i.e., data matching). MG gave oversight about writing and provided feedback to the final edited manuscript.

\section{FUNDING}

This work was supported by the German Research Foundation (DFG) and the Technical University of Munich (TUM) in the framework of the Open Access Publishing Program. 107, 238-246. doi: 10.1037/0033-2909.107.2.238

Bollen, K. A. (1989): Structural Equations with Latent Variables. New York, NY: John Wiley \& Sons. doi: 10.1002/9781118619179

Bollen, K. A. (1990). Overall fit in covariance structure models: two types of sample size effects. Psychol. Bull. 107, 256-259. doi: 10.1037/0033-2909.107. 2.256 
Bondorf, N. (2013): Profession und Kooperation: Eine Verhältnisbestimmung am Beispiel der Lehrerkooperation. [Profession and Cooperation. A Defining Relationship Using the Example of Teacher Cooperation]. Wiesbaden: Springer VS. doi: 10.1007/978-3-531-19703-6

Borko, H. (2004). Professional development and teacher learning: mapping the terrain. Educ. Res. 33, 3-15. doi: 10.3102/0013189X033 008003

Bosker, R. J., and Hendriks, M. A. (1997). Betrouwbaarheid, Validiteit en Bruikbaarheid van een Instrumentarium Ten Behoeve van Schoolzelfevaluatie in Het Basisonderwijs. Enschede: Universiteit Twente, Onderzoek Centrum Toegepaste Onderwijskunde.

Brown, T. A. (2006). Confirmatory Factor Analysis for Applied Research. New York, NY: Guilford Press.

Burns, D., and Darling-Hammond, L. (2014). Teaching Around the World: What Can TALIS Tell Us? Stanford, CA: Stanford Center for Opportunity Policy in Education.

Byrne, B. M. (2016). Structural Equation Modeling with AMOS: Basic Concepts, Applications, and Programming, 3rd Edn. New York, NY: Routledge.

Darling-Hammond, L., Hyler, M. E., and Gardner, M. (2017). Effective Teacher Professional Development. Palo Alto, CA: Learning Policy Institute.

Darling-Hammond, L., Wei, R., Adree, A., Richardson, N., and Orphanos, S. (2009). Professional Learning in the Learning Profession: A Status Report on Teacher Development in the United States and Abroad. National Staff Development Council. Retrieved from: https:/learningforward.org/docs/ default-source/pdf/nsdcstudy2009.pdf (accessed April 6, 2019).

Dattalo, P. (2013). Analysis of Multiple Dependent Variables. London: Oxford University Press. doi: 10.1093/acprof:oso/9780199773596.0 01.0001

Desimone, L. M. (2009). Improving impact studies of teachers' professional development: toward better conceptualizations and measures. Educ. Res. 38, 181-199. doi: 10.3102/0013189X08 331140

Ditton, H. (2000). Qualitätskontrolle und qualitätssicherung in schule und unterricht. ein überblick zum stand der empirischen forschung. [Quality control and quality assurance in school and teaching. An overview of the state of empirical research.]. Zeitschrift für Pädagogik 41, 73-92.

Drossel, K. (2015). Motivationale Bedingungen von Lehrerkooperation. Eine empirische Analyse der Zusammenrarbeit im Projekt "Ganz In". [Motivational Conditions of Teacher Collaboration. An Empirical Analysis of the Collaboration in the Project 'Ganz In']. Münster: Waxmann.

Dufour, R., Dufour, R., and Eaker, R. (2006). Learning by Doing. Bloomington, IN: Solution Tree.

DuFour, R., Eaker, R., and Dufour, R. (2005). On Common Ground: The Power of Professional Learning Communities. Bloomington, IN: Solution Tree.

Dumay, X., Boonen, T., and Van Damme, J. (2013). Principal leadership longterm indirect effects on learning growth in mathematics. Elem. School J. 114, 225-251. doi: $10.1086 / 673198$

Eisner, E. W. (1992). Educational reform and the ecology of schooling. Teach. Coll. Rec. 93, 610-627.

Esslinger, I. (2002). Berufsverständnis und Schulentwicklung: ein Passungsverhältnis? [Professional Understanding and School Development: A Match?]. Bad Heilbrunn/Obb.: Klinkhardt.

Fan, X., Thompson, B., and Wang, L. (1999). Effects of sample size, estimation methods, and model specification on structural equation modeling fit indexes. Struct. Equ. Model. 6, 56-83. doi: 10.1080/10705519909 540119

Field, A. (2013) Discovering Statistics Using IBM SPSS Statistics: And Sex and Drugs and Rock "N" Roll, 4th Edn. Los Angeles, CA; London; New Delhi: Sage.

Fimian, M. (1982). What is teacher stress? Clearing House 56, 1-106. doi: 10.1080/00098655.1982.10113746

Frey, A., Taskinen, P., Schütte, K., Prenzel, M., Artelt, C., Baumert, J., et al. (eds) (2009). PISA 2006: Skalenhandbuch. Dokumentation der Erhebungsinstrumente. Münster: Waxmann.

Friend, M., and Cook, L. (1992). The new including: how it really works. Instructor 101, 30-36 doi: $10.3817 / 1293094030$

Friend, M., and Cook, L. (2009). Interactions: Collaboration Skills for School Professionals, 6th Edn. Upper Saddle River, NJ: Prentice Hall.
Gaikwad, S., and Brantly, P. (1992). Teacher isolation-loneliness in the classroom. J. Adventist Educ. 54, 14-17.

Gebhardt, M., Schwab, S., Krammer, M., and Gegenfurtner, A. (2015). General and special education teachers' perceptions of teamwork in inclusive classrooms at elementary and secondary schools. J. Educ. Res. 7, 129-146.

Goddard, Y. L., Goddard, R. D., and Tschannen-Moran, M. (2007). A theoretical and empirical investigation of teacher collaboration for school improvement and student achievement in public elementary schools. Teach. Coll. Rec. $109,877-896$.

Goddard, Y. L., Miller, R., Larsen, R., Goddard, G., Jacob, R., Madsen, J., et al. (2010). "Connecting principal leadership, teacher collaboration, and student achievement," in Paper presented at the American Educational Research Association Annual Meeting (Denver, CO).

Graham, P. (2007). Improving teacher effectiveness through structured collaboration: a case study of a professional learning community. Res. Middle Level Educ. 31, 1-17. doi: 10.1080/19404476.2007.1 1462044

Gräsel, C., Fussangel, K., and Pröbstel, C. (2006). Die Anregung von Lehrkräften zur Kooperation - eine Aufgabe für Sisyphos? [The suggestion of teachers for cooperation - a task for Sisyphos?]. Zeitschrift für Pädagogik 52, 205-219.

Hair, J. F., Black, W. C., Babin, B. J., and Anderson, R. E. (2014). Multivariate Data Analysis, 7th Edn. New York, NY: Pearson.

Halinen, I. (2015). What is Going on in Finland? - Curriculum Reform 2016 $[$ Blog post $]$. Retrieved from the Finnish National Agency of Education Blog: https://www.oph.fi/english/current_issues/101/0/what_is_going_on_in_ finland_curriculum_reform_2016 (accessed November 27, 2018).

Hargreaves, A. (2003). Teaching in the Knowledge Society: Education in the Age of Insecurity. New York, NY: Teachers College Press.

Hargreaves, A., and Fullan, M. (2012). Professional Capital: Transforming Teaching in Every School. New York, NY: Teachers College, Columbia University

Hattie, J. (2003). "Teachers make a difference: what is the research evidence?" in Paper presented at the Australian Council for Educational Research Annual Conference on Building Teacher Quality (Melbourne, VIC). Retrieved from: http://research.acer.edu.au/research_conference_2003/4/

Hattie, J. (2015). What Works Best in Education: The Politics of Collaborative Expertise. London: Pearson.

Hidalgo-Cabrillana, A., and Lopez-Mayan, C. (2015). "Teaching practices and student achievement," in Paper presented at the Annual Meeting of the French Economic Association (Rennes). Retrieved from: https://afse2015.sciencesconf. org/58706/document

Hochweber, J., Steinert, B., and Klieme, E. (2012). Lehrerkooperation, unterrichtsqualität und lernergebnisse im fach englisch. [The impact of teacher cooperation and instructional quality on learning in English as a foreign language]. Unterrichtswissenschaft 40, 351-370.

Hu, L., and Bentler, P. (1999). Cutoff criteria for fit indexes in covariance structure analysis: conventional criteria versus new alternatives. Struct. Equ. Model. 6, 1-55. doi: 10.1080/10705519909 540118

Jackson, C. K., and Bruegmann, E. (2009). Teaching students and teaching each other: the importance of peer learning for teachers. Am. Econ. J. 1, 85-108. doi: $10.3386 /$ w15202

Johnson, B. (2003). Teacher collaboration: good for some, not so good for others. Educ. Stud. 29, 337-350. doi: 10.1080/030556903200 0159651

Kaiser, H. (1974). An index of factor simplicity. Psychometrika 39, 31-36. doi: $10.1007 / \mathrm{BF} 02291575$

Kelchtermans, G. (2006). Teacher collaboration and collegiality as workplace conditions: a review. Zeitschrift für Pädagogik $52,220-237$.

Kullmann, H. (2013). "Der Zusammenhang von Lehrerkooperation und Schulleistung - Zentrale Befunde und Perspektiven für die Forschung [The relationship between teacher collaboration and school performance - central findings and perspectives for research]," in Professionalität und Kooperation 
in Schulen. Beiträge zur Diskussion über Schulqualität [Professionalism and cooperation in schools. Contributions to the discussion about school quality.], eds M. Keller-Schneider, S. Albisser, and J. Wissinger (Bad Heilbrunn: Julius Klinkhardt), 123-137.

Kulturministerkonferenz (2014). "Standards für Die Lehrerbildung: Bildungswissenschaften," in Beschluss der Kultusministerkonferenz vom 16.12.2004 i. d. F. vom 12.06.2014. Available online at: https://www.kmk. org/fileadmin/veroeffentlichungen_beschluesse/2004/2004_12_16-StandardsLehrerbildung-Bildungswissenschaften.pdf (accessed July 22, 2018).

Kultusministerkonferenz (2003). Bildungsbericht für Deutschland. Erste Befunde. Available online at: http://www.kmk.org/fileadmin/veroeffentlichungen_ beschluesse/2003/2003_01_01-Bildungsbericht-erste-Befunde.pdf (accessed June 6, 2015).

Kunter, M., and Pohlmann, B. (2009). "Lehrer [Teacher]," in Pädagogische Psychologie, eds E. Wild and J. Möller (Berlin; Heidelberg: Springer-Lehrbuch. Springer), 961-288. doi: 10.1007/978-3-540-88 573-3_11

Lara-Alecio, R., Tong, F., Irby, B. J., Guerrero, C., Huerta, M., and Fan, Y. (2012). The effect of an instructional intervention on middle school English learners' science and English reading achievement. J. Res. Sci. Teach. 49, 987-1011. doi: $10.1002 /$ tea. 21031

Lee, V. E., and Smith, J. B. (1996). Collective responsibility for learning and its effects on gains in achievement for early secondary school students. Am. J. Educ. 104, 103-147. doi: 10.1086/444122

Little, J. W. (1990). The persistence of privacy: autonomy and initiative in teachers professional relations. Teach. College Record 91, 509-536.

Lortie, D. C. (1975). Schoolteacher: A Sociological Study. Chicago, IL: University of Chicago Press.

Louis, K. S., Dretzke, B., and Wahlstrom, K. (2010). How does leadership affect student achievement? Results from a national US survey. School Effect. School Improv. 21, 315-336 doi: 10.1080/09243453.2010. 486586

Luster, J. N. G. (1993). A Study of Collaborative Consultation versus Traditional Methods of Special Education Service Delivery (LSU Historical Dissertations and Theses). 5581. Available online at: https://digitalcommons.lsu.edu/gradschool_ disstheses/5581 (accessed March 11, 2019).

MacCallum, R., Browne, M., and Sugawara, H. (1996). Power analysis and determination of sample size for covariance structure modeling. Psychol. Methods 1, 130-149. doi: 10.1037/1082-989X.1. 2.130

Marsh, H. W., Hau, K.-T., and Grayson, D. (2005). "Goodness of fit in structural equation models," in Multivariate Applications Book Series. Contemporary Psychometrics: A Festschrift for Roderick P. McDonald, eds A. MaydeuOlivares and J. J. McArdle (Mahwah, NJ: Lawrence Erlbaum Associates Publishers), 275-340.

Marsh, H. W., Hau, K.-T., and Wen, Z. (2004) In search of golden rules: comment on hypothesis-testing approaches to setting cutoff values for fit indexes and dangers in over generalizing $\mathrm{Hu}$ and Bentler's (1999) findings. Struct. Equ. Model. 11, 320-341. doi: 10.1207/s15328007sem 1103_2

Meirink, J. A., Imants, J., Meijer, P. C., and Verloop, N. (2010). Teacher learning and collaboration in innovative teams. Cambridge J. Educ. 40, 161-181. doi: 10.1080/0305764X.2010.481256

Moolenaar, N. M., Sleegers, P. J., and Daly, A. J. (2012). Teaming up: linking collaboration networks, collective efficacy, and student achievement. Teach. Teach. Educ. 28, 251-262. doi: 10.1016/j.tate.2011.10.001

Mora-Ruano, J. G., Gebhardt, M., and Wittmann, E. (2018). Teacher Collaboration in german schools: do gender and school type influence the frequency of collaboration among teachers? Front. Educ. 3:55. doi: 10.3389/feduc.2018. 00055

Mostafa, T., and Pál, J. (2018). "Science teachers' satisfaction: evidence from the PISA 2015 teacher survey," in OECD Education Working Papers, 168 (Paris: OECD Publishing). doi: 10.1787/1ecdb4e3-en

Newsom, J. (2018). Some Clarifications and Recommendations on Fit Indices [Class handout]. Psy 523/623: Structural Equation Modeling, Spring 2018. Portlant, OR: Department of Psychology, Portland State University. Retrieved from: http://web.pdx.edu/ newsomj/semclass/ (accessed February 21, 2019)
Nunnally, J. C., and Bernstein, I. H. (1994). Psychometric Theory 3rd Edn. New York, NY: McGraw-Hill.

OECD (2004). Completing the Foundation for Lifelong Learning: An OECD Survey of Upper Secondary Schools. Paris: OECD. doi: 10.1787/97892641 03733-en

OECD (2014). "What helps teachers feel valued and satisfied with their jobs?" Teaching in Focus, No. 5. Paris: OECD Publishing. doi: $10.1787 / 5 j x z b t w 4 g z g 3-e n$

Piepenburg, U. (1991). "Ein Konzept von Kooperation und die technische Unterstützung kooperativer Prozesse in Bürobereichen," in Computergestützte Gruppenarbeit (CSCW) [Computer-aided group work], eds J. Friedrich, and K.-H. Rödiger (Stuttgart: B.G. Teubner), 79-94. doi: 10.1007/978-3-322-92140-6_4

Prenzel, M., Sälzer, C., Klieme, E., Köller, O., Mang, J., Heine, J.-H., et al. (2015). Programme for International Student Assessment 2012 (PISA 2012). Version: 2. IQB - Institut zur Qualitätsentwicklung im Bildungswesen. Datensatz. doi: 10.5159/IQB_PISA_2012_v2

Puchner, L. D., and Taylor, A. R. (2006). Lesson study, collaboration and teacher efficacy: stories from two school based math lesson study groups. Teach. Teach. Educ. 22, 922-934. doi: 10.1016/j.tate.2006. 04.011

Reeves, P., Pun, W., and Chung, K. (2017). Influence of teacher collaboration on job satisfaction and student achievement. Teach. Teach. Educ. 67, 227-236. doi: $10.1016 /$ j.tate.2017.06.016

Reinhardt, S. (2000). "Kooperation," in Lexikon der Politischen Bildung, Vol. 3. [Encyclopedia of political education], ed G. Weißeno (Schwalbach), 91.

Ronfeldt, M., Farmer, S. O., Kiel, M., and Grissom, J. A. (2015). Teacher collaboration in instructional teams and student achievement. Am. Educ. Res. J. 52, 475-514. doi: 10.3102/0002831215585562

Sälzer, C., and Prenzel, M. (2013). "PISA 2012 - eine Einführung in die aktuelle studie [PISA 2012 - an introduction to the current study]," in PISA 2012 Fortschritte und Herausforderungen in Deutschland [PISA 2012 - Advances and Challenges in Germany], eds M. Prenzel, C. Sälzer, E. Klieme, and O. Köller (Münster: Waxmann), 11-43.

Schacter, J., and Thum, Y. M. (2004). Paying for high- and low-quality teaching. Econ. Educ. Rev. 23, 411-430. doi: 10.1016/j.econedurev.2003. 08.002

Schafer, J. L., and Graham, J. W. (2002). Missing data: our view of the state of the art. Psychol. Methods, 7, 147-177. doi: 10.1037/1082-989X.7.2.147

Scheerens, J. (2000). Improving School Effectiveness. In: Unesco (Ed.): Fundamentals of Educational Planning, 68. Paris.

Schermelleh-Engel, K., Moosbrugger, H., and Müller, H. (2003). Evaluating the fit of structural equation models: tests of significance and descriptive goodness-offit measures. Methods Psychol. Res. 8, 23-74.

Schumacker, R. E., and Lomax, R. G. (1996). A Beginner's Guide to Structural Equation Modeling. Mahwah, NJ: Lawrence Erlbaum Associates.

Schwab, S. (2017). Interprofessionelle Lehrkraftkooperation im inklusiven Unterricht aus der Perspektive der Schülerinnen und Schüler. [Interprofessional teacher cooperation in inclusive education from the perspective of students.]. Unterrichtswissenschaft 45, 262-279. doi: 10.3262/UW1704262

Spieß, E. (2004). "Kooperation und konflikt," in Organisationspsychologie-Gruppe und Organisation [Organizational Psychology - Group and Organization], ed H Schuler (Göttingen: Hogrefe), 193-247.

Steiger, J. H., and Lind, J. C. (1980). "Statistically-based tests for the number of common factors," in Paper presented at the Annual Spring Meeting of the Psychometric Society (Iowa City, IA).

Svendsen, B. (2016) Teachers' experience from a school-based collaborative teacher professional development programme: reported impact on professional development. Teach. Dev. 20, 313-328. doi: 10.1080/13664530.2016. 1149512

Trumpa, S., Franz, E.-K., and Greiten, S. (2016). Forschungsbefunde zur kooperation von lehrkräften - ein narratives review [Research results on teacher cooperation - a narrative review]. Die Deutsche Schule 108, 82-94.

Tucker, L. R., and Lewis, C. (1973). A reliability coefficient for maximum likelihood factor analysis. Psychometrika 38, 1-10. doi: 10.1007/BF022 91170 
Vandenberg, R. J. (2006). Statistical and methodological myths and urban legends. Org. Res. Methods 9, 194-201. doi: 10.1177/1094428105285506

Vincent-Lancrin, S., G., Jacotin, J., Urgel, S., Kar, and, C., González-Sancho (2017). Measuring Innovation in Education: A Journey to the Future. Paris: OECD Publishing.

Williams, M. L. (2010). Teacher collaboration as professional development in a large, suburban high school (Dissertation). University of Nebraska, Lincoln, OR; Omaha, NE, United States.

Woodland, R., Lee, M. K., and Randall, J. (2013). A validation study of the teacher collaboration assessment survey. Educ. Res. Evalu. 19, 442-460. doi: $10.1080 / 13803611.2013 .795118$
Conflict of Interest Statement: The authors declare that the research was conducted in the absence of any commercial or financial relationships that could be construed as a potential conflict of interest.

Copyright (๑) 2019 Mora-Ruano, Heine and Gebhardt. This is an open-access article distributed under the terms of the Creative Commons Attribution License (CC BY). The use, distribution or reproduction in other forums is permitted, provided the original author(s) and the copyright owner(s) are credited and that the original publication in this journal is cited, in accordance with accepted academic practice. No use, distribution or reproduction is permitted which does not comply with these terms. 


\section{APPENDIX A}

Question 21

\section{Construct:}

Item text:

Data source:

Answer format:

Literature/Remarks:

Number of items:

Categories:

Collaboration (forms)

How often do you use the following forms of collaboration with colleagues?

National questionnaire for teachers (biology, chemistry, physics, natural science or mathematics).

Rating scale

Bosker and Hendriks (1997). Adaptation by the IPN. Mora-Ruano et al. (2018) modifications to the Likert categories

17

$1=$ never

$2=$ once in a year

3 = several times in a year / every month

4 = every week / every day

\begin{tabular}{|c|c|}
\hline Item ID & Item text \\
\hline i21_01 & Exchange of teaching materials ${ }^{a}$ \\
\hline i21_02 & Exchange of examination questions ${ }^{\mathrm{a}}$ \\
\hline i21_03 & Preparation of individual lessons ${ }^{\mathrm{a}}$ \\
\hline i21_04 & Joint planning of entire lessons or projects ${ }^{b}$ \\
\hline i21_05 & Planning interdisciplinary lessons ${ }^{b}$ \\
\hline i21_06 & Joint implementation of lessons ${ }^{b}$ \\
\hline i21_07 & Testing new teaching ideas and methods ${ }^{\mathrm{b}}$ \\
\hline i21_08 & Peer observation ${ }^{b}$ \\
\hline i21_09 & Reconciliation of dealing with homework ${ }^{\mathrm{c}}$ \\
\hline i21_10 & Interdisciplinary discussion of student performance ${ }^{\mathrm{c}}$ \\
\hline i21_11 & Preparation of replacement hours ${ }^{c}$ \\
\hline i21_12 & Follow-up lessons ${ }^{a}$ \\
\hline i21_13 & Monitoring and advising new teachers ${ }^{\mathrm{a}}$ \\
\hline i21_14 & Joint promotion of slow pupils ${ }^{c}$ \\
\hline i21_15 & Preparation of written exams ${ }^{b}$ \\
\hline i21_16 & Advice on the assessment of student performance ${ }^{C}$ \\
\hline i21_17 & Joint promotion of high-performance students ${ }^{C}$ \\
\hline
\end{tabular}

a Dimension "instruction" b Dimension "project" cDimension "organization, performance, and problems". 